\title{
Political Connection and Firm Value in Indonesia
}

\author{
Versiandika Yudha Pratama* | Doddy Setiawan \\ Faculty of Economics and Business, Universitas Sebelas Maret, Indonesia
}

\begin{abstract}
This is an event study aims to determine the influence of political connections to firm value as measured by cumulative abnormal return on non-financial sector companies listed in Indonesia Stock Exchange. This study used secondary data in the form of stock price and annual financial statement obtained the Indonesia Stock Exchange website, Indonesian Capital Market Directory, and other relevant sources. In sampling technique, purposive sampling method is used where 272 non-financial sector companies are selected. The data is examined by using multiple linear regression to measure the influence of political connections on firm value. The findings of this study revealed that political connections have an effect on firm value as measured by cumulative abnormal return on non-financial sector companies listed in Indonesia Stock Exchange.
\end{abstract}

Keywords: Political Connections, Firm Value, Cumulative Abnormal Return

\section{Introduction}

The long-term goal of the company is to maximize or optimize firm value for it reflects the company's market price. The higher firm value describes the more prosperous the owner (Fama, 1978; Nicholson and Wilson, 1987; Walker, 2000; Wright and Ferris, 1997). Optimizing the firm value can be achieved by the implementation of financial management function, in this case a financial decision will affect other decisions and impact on value of the company. Important decisions taken by the company include funding and investment decisions, also dividend policies (Fama and French, 1998).

One of basic principles investors use in investment decision-making is to analyze the movement of stock prices or stock returns in the capital market mainly caused by information about economic policy, political, social, and human rights condition. As an economic instrument, the capital market can't be separated from the various things that happen around it. The more important the role of capital market in the economy of a country, the more sensitive capital market to the things that affect. Political issues can't be separated from the reaction that occurs in the capital market (Hartwell, 2015). This political issue is closely related to the stability and economic performance of a country. There are several political issues which obtain a big response from investor, such as coup d'etat, regime change, presidential election and riots. To those issues, Indonesia includes in a country with very high risk category (Asri and Setiawan, 1998).

According to Faccio (2006), company has political connections if at least one of the company's largest shareholders (i.e, anyone directly or indirectly controls $10 \%$ of the vote) or the board of directors is a head of state, a minister, or member of parliament, or is someone who has a close relationship with

\footnotetext{
* Corresponding author at Jl. Ir Sutami No.36 A, Pucangsawit, Kec. Jebres, Kota Surakarta, Jawa Tengah 57126, Indonesia. Email: versiandikayudha@gmail.com
} 
politicians. This opinion is supported by Purwoto (2011) who defines that company with political connection is that in certain ways has political relationship with politicians or government.

Political connections are common in developing countries with the protection of weak property rights, including Indonesia (Fisman, 2001). In Indonesia, this phenomenon occurred since President Soeharto regime. A research conducted by Mobarak and Purbasari (2006) claims that in Indonesia, company having connections to the regime has its own advantages in terms of obtaining import permits compared to competitors who do not.

This study is a replication to research of Daron et al. (2016) entitled "The Value of Connections in turbulent times: The Evidence from the United States", that examines political connections that affect firm value of company having a connection with the new Finance Minister in President Obama government, Timothy Geithner, during turbulence. In Indonesia, referring to the turbulence after direct presidential election in 2014 won by Joko Widodo, it is important to find out whether political connection under President Joko Widodo inauguration affect the value of companies that have connections to the government. This study was conducted to find out the effect of affiliation between company and politic through board of commissioners, board of directors and shareholders in influencing company value as measured by cumulative abnormal return (CAR).

\section{Theoretical Background and Hypothesis}

\section{Firm Value}

The main objectives of the company are Stockholder Wealth Maximization (Brigham and Houston, 2001). Maximizing the wealth of the owner or shareholder is identical to maximizing the value of the firm, in accordance with the opinion of Besley and Brigham (2000) stating that the firm value is reflected in the stock price, especially for companies that trade its shares to the public. Higher firm value will be followed by higher shareholder wealth and higher stock price.

In this research, firm value measured by the cumulation of abnormal return (CAR). The Cumulative Abnormal Return (CAR) represents the accumulation of abnormal return during the event period for each stock.

\section{Political Connections}

Company which has a political connection is a that in certain ways has political relationship with politicians or government (Purwoto, 2011). Gomez and Jomo (2009) state that companies with political connections are companies or conglomerates with close government relationships. According to Faccio (2006), a company can be said to have a political relationship if at least one of the majority shareholders (one who controls at least 10 percent of the total shares with voting rights) or one of the company's directors is a member of parliament or persons closely affiliated with top politicians or political parties.

Several related studies have explained and provided evidence of the influence of political relationships on the firm value. Goldman et al. (2006) prove that political relations have an influence on firm value, while unrelated companies don't have influence on firm value. Do et al. (2012)prove that political relation to the elected governor increases the value of the company. Study in Indonesia on political connection and company value done by Revelino (2015)which showed that political connection with KIH has a positive effect firm value. While the one with KMP negatively affect firm value. Based on the previous study, the hypothesis of this research is formulated as follows:

\section{H1: Political connections with Joko Widodo's government have a significant effect on the firm value in Indonesia.}




\section{Research Model}

Based on the proposed hypothesis, the framework of the research model is described as follows:

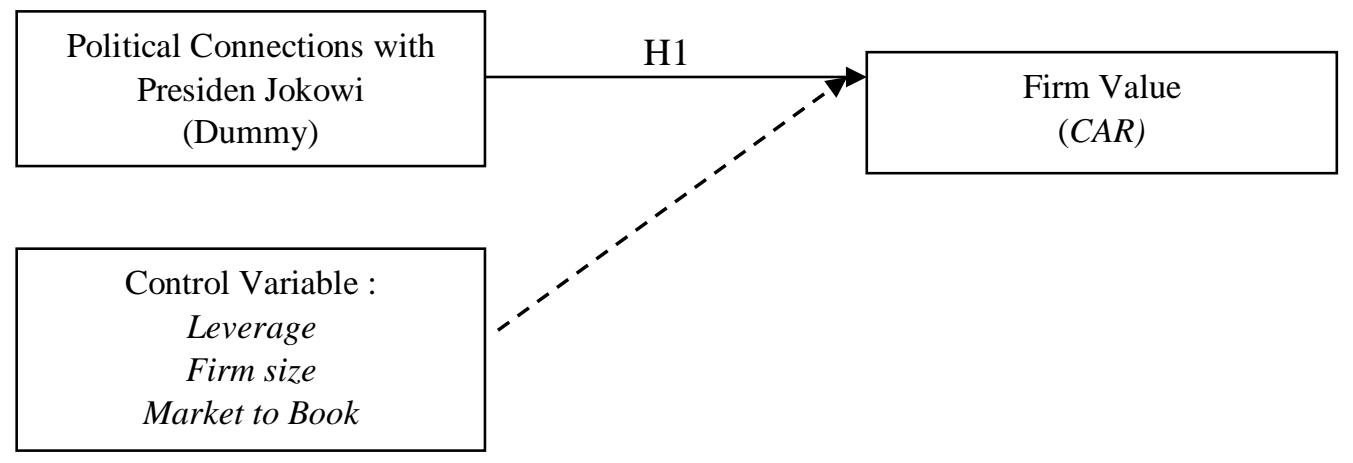

Figure 1. Research Framework

\section{Research Methods}

This study is an event study used secondary data in the form of stock price and annual financial statement obtained from www.idx.co.id., ICMD and other relevant sources. The population in this study were 414 companies in the Non-Financial Sector which is officially listed on the Indonesia Stock Exchange (IDX) during the observation period. Purposive sampling method is used as the sampling technique because this method is based on specific objectives with the criteria that have been determined to obtain a sample that is capable in representing the population which suit the characteristics of this study. From this kind of technique, 272 companies have been obtained as research samples. In analyzing the data, multiple linear regression and classical assumptions are employed.

Table 1. Sample Determination Process

\begin{tabular}{lc}
\hline Criteria & Total \\
\hline Population & 414 \\
1. Non-financial companies are incomplete closing stock price data. & $(98)$ \\
2. Non-financial companies are not complete data on total assets, & $(28)$ \\
$\quad$ liabilities, shared and equity listings. & $(16)$ \\
3. It has extreme value & 272 \\
\hline Final sample & \\
\hline
\end{tabular}

Before analyzing the data, we test the CAR to see the market reactions about the inauguration of President Joko Widodo on October 20, 2014 used paired sample t-test. The event window used in this research is for 11 trading days covering 5 days before the event, 1 day at the time of the event and 5 days after the inauguration of the president. Meanwhile, the estimated period is set for 120 trading days. The event date (day 0) is set on October 20, 2014 for the inauguration of President Joko Widodo.

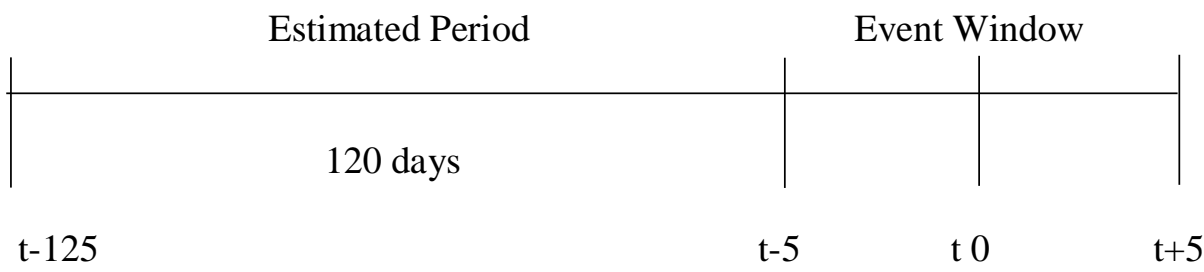

Figure 2. Estimated Period and Event Window of the Research 


\section{Findings and Discussions}

Testing begins with paired sample t-test to see if there is a difference between cumulative abnormal return before and after the inauguration of President Joko Widodo. The statistical results of paired sample t-test show that the significance value of $0.013(0.013<0.05)$, it can be concluded that there is a difference in cumulative abnormal returns before and after the inauguration of President Joko Widodo.

Table 2. Market Reaction Testing (Paired Sample t-test)

\begin{tabular}{ccccc}
\hline & $\mathrm{t}$ & $d f$ & Sig (2-tailed) & Information \\
\hline BEFORE - & 2.505 & 271 & 0.013 & $\begin{array}{c}\text { There is a } \\
\text { difference }\end{array}$ \\
AFTER & & & & \\
\hline
\end{tabular}

After seeing a market reaction testing which indicates that there is a difference in cumulative abnormal returns before and after the inauguration of President Joko Widodo, the next step is do the classical assumption and multiple linear regression testing.

\section{Classical Assumption Testing}

Table 3. Normality Testing Result

\begin{tabular}{cccc}
\hline Method & $\mathrm{N}$ & Asymp.Sig. (2-tailed) & Information \\
\hline $\begin{array}{l}\text { One-Sample } \\
\text { Kolmogorov- }\end{array}$ & 272 & 0.212 & Distributed normally \\
Smirnov & & & \\
\hline
\end{tabular}

Based on the results of normality test using Kolmogorov-Smirnov Z obtained Asymp value. Sig. (2-tailed) more than 0.05 that is equal to 0.212 . It means that data has been distributed normally.

Table 4. Glejser Testing Result

\begin{tabular}{ccc}
\hline Method & Variable & Sig. \\
\hline Glejser & POL & 0.139 \\
& SIZE & 0.208 \\
& LEV & 0.981 \\
& MTB & 0.365 \\
\hline
\end{tabular}

From the output table 4 above can be seen that the value of independent variables with Unstandardized Residual has a significance value of more than 0,05 . Therefore, there was no problem of heteroscedasticity in the regression model.

Table 5. Multicollinearity Testing Result

\begin{tabular}{cccc}
\hline Variable & Tolerance & VIF & Conclusion \\
\hline POL & 0.862 & 1.160 & No multicollinearity \\
SIZE & 0.848 & 1.179 & No multicollinearity \\
LEV & 0.992 & 1.008 & No multicollinearity \\
MTB & 0.969 & 1.032 & No multicollinearity \\
\hline
\end{tabular}

Multicollinearity testing result above shows that all of variables have a VIF value $<10$ and no variable has a tolerance value less than 0.1 . This means that the regression model in this research is free from multicollinearity.

Table 6 shows that the Durbin-Watson value is 2.133 with the value of du is 1.8230 and 4 -du equal to 2.177. It can be concluded that Durbin-Watson value (d) is at $\mathrm{du}<\mathrm{d}<4$-du. That means the regression model used in this study is free of symptoms of autocorrelation. 
Table 6. Autocorrelation Testing Result

\begin{tabular}{cccc}
\hline Method & Durbin Watson & du table & dl table \\
\hline $\begin{array}{c}\text { Durbin-Watson } \\
\text { Testing }\end{array}$ & 2.133 & 1.77808 & 1.8230 \\
\hline
\end{tabular}

\section{Hypothesis Testing}

To find out the influence of independent variable to dependent variable in regression model, it will be done by multiple linear regression analysis by using SPSS. The results of multiple linear regression analysis can be seen in table 7 below.

Table 7. Multiple Linear Regression Analysis Result

\begin{tabular}{cccc}
\hline Variable & Coefficients $(\beta)$ & $\mathrm{t}$ value & Sig. \\
\hline Constant & -0.122 & -1.872 & 0.062 \\
POL & 0.033 & 2.773 & 0.006 \\
SIZE & 0.005 & 1.993 & 0.047 \\
LEV & -0.004 & -2.209 & 0.028 \\
MTB & 0.001 & 0.608 & 0.543 \\
\hline F value & & 5.816 & \\
Sig. F & & 0.000 & \\
$R$ Square & & 0.080 & \\
Adj $R$ Squre & & 0.066 & \\
\hline
\end{tabular}

From table 7 above, it is known that the $\mathrm{F}$ value is 5.816, while the $\mathrm{F}$ table at significance level of $5 \%$ is 2.4053 which means that $F$ value $>F$ table. In addition, the significance value of $0.019<0.05$. It can be concluded that POL, SIZE, LEV and MTB variables included in the regression model had a mutual influence on the dependent variable (CAR). While for t-test, it is seen that the level of significance on the independent variable POL of 0.006 whose value is smaller than 0.05 . This means that political relation with Joko Widodo's government have a significant effect on firm value. The level of significance on control variables SIZE of 0.047, LEV of 0.028 and MTB variable of 0.543 . This indicates that firm size and leverage have significant effect to firm value, while market to book value of equity has no significant effect to firm value.

\section{Discussions}

Based on statistical findings, it can be seen that the political connections have a significance value of 0.006 , lower than 0.05 which means the political connection significantly affect the firm value. This indicates that companies connected with the government will increase the firm value. This is reinforced by the results of calculations showing that companies which connected with Joko Widodo's government have a positive cumulative abnormal return.

A company with a relationship with the government will obtain strategic benefits such as knowing government regulations earlier. For example, when the government removes subsidies for gasoline and diesel, the company at least already knows with the policy that the government wants to make so the company has prepared the steps of anticipation. According to (Goldman et al., 2006) the company even benefits particularly in terms of reducing competition costs, reducing regulatory obligations or more easily in obtaining contracts related to government projects. As an example, in Indonesia, the company winning tenders for toll road projects is mostly a state-owned company that clearly has a political connection with the government in power.

The results of this study are in line with a study conducted by (Goldman et al., 2006) which proves that political relations have an influence on corporate value, while non-political companies have no influence on corporate value. And support the results of a study of Do et al. (2012) proving that the connection of political connections to the elected governor increases the corporate value. These results are in line with the hypothesis proposed in this study. Accordingly, it can be stated that the hypothesis of this study is accepted. 
For the size of the company, the statistic result finds that the size has a significance value of 0.047 lower than 0.05 which means that the firm size significantly influences the firm value. It means that the size of a large company causes the company's value to be higher as well. This is because large companies tend to have stable conditions that cause stock prices to rise in the stock market. Thus, investors have large expectations of the company's shares. Increased demand for shares of the company will spur on the increase in stock prices in the capital market so that the firm value will also increase.

At leverage, the test statistic shows that leverage has a significance value of 0.028 lower than 0.05 which means that leverage has a positive effect on the value of the company. This means that companies in funding their assets use debt effectively. Effective use of debt will result in profits that have an impact on increasing corporate value. Increased debt ratio in a company is said to be a positive signal for investors with the assumption that the company's cash flow in the future is maintained and shows optimism from management in making investment so it is expected that in the future the company's prospect will be bright.

Market to book value of equity is market ratio to measure company growth through comparison of stock market value with stock book value reflecting investment opportunity based on price and capital of a company. Market to book value of equity has a significance value of 0.543 , greater than 0.05 which means that the market to book value of equity has no significant effect on corporate value. Its means that the average company in the sample has a stock market price smaller than its share book value that makes many companies non-growth. This is bad news for investors and companies that do not grow will be responded negatively by the market causing the value of the company decreased. The result of this research is in line with research of Revelino (2015) which states that market to book value of equity has no significant effect on corporate value

\section{Conclusion}

Based on the results of data testing, it can be concluded that the political connection proved to significantly affecting the firm value of non-financial sector listed on the Indonesia Stock Exchange. Companies connected with the government will increase the firm value. Moreover, our result show that that companies which connected with Joko Widodo's government have a positive cumulative abnormal return. A company with a relationship with the government will obtain strategic benefits such as knowing government regulations earlier. As an example, in Indonesia, the company winning tenders for toll road projects is mostly a state-owned company that clearly has a political connection with the government in power.

\section{References}

Asri, M. and Setiawan, F. (1998), Indonesia Capital Market Reaction to Domestic Political Event, Inherent Digital Library, Vol. 7 .

Besley, S. and Brigham, E.F. (200o), Essentials of Managerial Finance 12th Edition, Dryden Press, Fort Worth.

Brigham, E.F. and Houston, J.F. (2001), Financial Management, Erlangga, Jakarta.

Daron, A., Johnson, S., Kermani, A. and Kwak, J. (2016), "The value of connections in turbulent times: Evidence from the United States", Journal of Financial Economics, Vol. 121, pp. 368-391.

Do, Q.-A., Lee, Y.-T. and Nguyen, B.-D. (2012), "Political Connections and Firm Value: Evidence from the Regression Discontinuity Design of Close Gubernatorial Elections", Evaluation of Democracy Research Group, LIEPP Working Paper.

Faccio, M. (2006), "Politically Connected Firms", The American Economic Review, Vol. 68, pp. 369-386.

Fama, E.F. (1978), “The Effect of a Firm's Investment and Financing Decision on the Welfare of its Security Holders", American Economic Review, Vol. 68, pp. 272-278.

Fama, E.F. and French, K. (1998), "Value versus Growth : The International Evidence", The Journal of Finance, Vol. 53, pp. 1975-1999.

Fisman, R. (2001), "Estimating the Value of Political Connections", American Economic Review, Vol. 91, pp. $1095^{-1102 .}$

Goldman, E., Rocholl, J. and So, J. (2006), "Political Connections and the Allocation of Procurement Contracts", Working Paper.

Gomez, E.T. and Jomo, K.S. (2009), "Malaysia's Political Economy: Politics, Patronage And Profits", Cambridge Journal.

Hartwell, C. (2015), “Political Volatility and Capital Markets : Evidence from Transition”, HKUST Institut Emerging Markets Studies Working Paper.

Mobarak, A. and Purbasari. (2006), "Corrupt protection for sale to firms: Evidence from Indonesia", Yale University, 
Mimeograph.

Nicholson, J.W. and Wilson, A.D. (1987), "Thermal Behaviour of Films of Partially Neutralized Poly(Acrylic Acid). 2: the Influence of Univalent Cations.”, British Polymer Journal, Vol. 19 No. 5, pp. 449-452.

Purwoto, L. (2011), "The Influence of Political Connection, Government Ownership and Opacity of Financial Statements on Synchronization and Risk of Stock Price Crashes", Summary of Dissertation PDIE Manajemen Universitas Gadjah Mada.

Revelino, D. (2015), "Analysis of the Influence of Political Connection on Corporate Value (Koalisi Indonesia Hebat dan Koalisi Merah Putih)”, Faculty of Economics and Business Universitas Diponegoro Semarang.

Walker, M.M. (2000), "Corporate Takeovers, Strategic Objectives, and Acquiring Firm Shareholders Wealth", Financial Management, Vol. 29, pp. 36-46.

Wright, P. and Ferris, P.S. (1997), "Agency Conflict and Corporate Strategy: The Effect of Divestment on Corporate Value”, Strategic Management Journal, Vol. 18, pp. 77-83. 